\title{
Girls left behind: Redirecting HIV interventions toward the most vulnerable
}

Judith Bruce

Population Council

Follow this and additional works at: https://knowledgecommons.popcouncil.org/departments_sbsr-pgy

Part of the Demography, Population, and Ecology Commons, Family, Life Course, and Society Commons, Gender and Sexuality Commons, and the International Public Health Commons How does access to this work benefit you? Let us know!

\section{Recommended Citation}

Bruce, Judith. 2007. "Girls left behind: Redirecting HIV interventions toward the most vulnerable," Promoting Healthy, Safe, and Productive Transitions to Adulthood Brief no. 23. New York: Population Council. 


\section{Girls left behind: Redirecting HIV interventions toward the most vulnerable}

\section{Prepared by Judith Bruce}

A $s$ we enter the third decade of the HIV pandemic in sub-Saharan Africa, young women-often adolescent girls-are the new face of the disease. In particular, HIVIAIDS is threatening those girls and young women with limited social and economic assets-those who are unable to avoid, manage, or leave unsafe sexual relationships inside and outside of marriage.

Out-of-school girls, especially those aged 10-14 living apart from their families, are particularly vulnerable. Those who are newly migrated to urban areas, especially those in domestic service, and girls who are taking care of HIVinfected families or otherwise serving as heads of households, may be under substantial pressure to support themselves, parents, or siblings. Married girls are subject to frequent unprotected sexual relations, often with older partners, and may, therefore, face elevated risk of HIV infection.

Girls at risk of sexual exploitation are not a small minority; they are counted in the hundreds of millions. Yet despite their numbers, most are untouched by existing interventions. Indeed, the majority of health, social development, livelihoods, and youth programs are failing to reach the most vulnerable girls living in the path of HIV.

\section{Structural determinants of risk}

The vulnerability of adolescent girls to HIV, particularly in sub-Saharan Africa, is rooted in the following key structural conditions: (1) social isolation, (2) absence from school during adolescence, (3) child marriage, (4) unsafe sexual activity, and (5) pressure to provide productive labor and income.

\section{Social isolation}

An overarching structural impediment for many girls and young women is their high degree of social isolation. In the context of the HIV pandemic, this isolation has important consequences. The most socially isolated girls in KwaZuluNatal, South Africa, for example, are six times more likely to have been physically forced to have sex than the most socially connected girls (Hallman and Diers 2004). Social isolation, poverty, orphan status, and school-going status have been independently linked with sexual coercion and exchange of sex for gifts, money, shelter, and food (Hallman 2004 and 2005; Hallman and Diers 2004). Among 18-24year-old females in KwaZulu-Natal, higher social capital is correlated with greater exposure to HIV messages in the media, fewer sexual partners, and a greater likelihood of having had an HIV test (Hallman et al. 2007).

Consistently across income groups, girls have smaller and less reliable friendship networks than boys and fewer safe and supportive spaces in which to meet their friends (Erulkar et al. 2004b; Hallman and Diers 2004). A recent study in Kibera, Kenya-a community of 800,000 and the largest slum in Africa-found that of the 90,000 adolescent girls aged 10-19 living there, only about one-fourth reported that they have a safe place to gather with other girls of their own age outside of home and school (Erulkar and Matheka 2007). A companion participatory study conducted by girl leaders found that less than 1 percent had access once a week to even minimal social programs in a girls-only space. 
Their negligible access to girl-friendly spaces is not only an emotional loss, but it also denies them potential program platforms that could provide them with information, help them build their skills, and offer them services directly or by referral.

\section{Being out of school}

Young, out-of-school girls face substantial threats to their health and safety from exploitative labor conditions in urban areas and, in rural areas, pressure to marry early. For many, migration away from poor opportunities and unsafe marriage to uncertain prospects in the city is a related, dangerous phenomenon (Erulkar et al. 2004a and 2004b).

A global review of school enrollment revealed that currently enrolled unmarried girls aged 15-17 were substantially less likely than girls of that age who were not enrolled to have had sexual relations; they also had lower rates of pregnancy and sexually transmitted diseases (Lloyd 2005).

\section{Child marriage}

If present patterns continue, during the next ten years 100 million girls will be married as children. The sexual health of married girls is at greater risk than that of unmarried girls. Married girls typically have partners that are older than the partners of their sexually active unmarried counterparts. They face intense pressure to become pregnant before their bodies are ready to bear children and have a higher frequency of sexual activity than their sexually active unmarried peers (Clark 2004; Clark, Bruce, and Dude 2006). Married adolescent girls tend to have limited or no peer networks, restricted social mobility, low educational attainment (and virtually no schooling options), and limited access to modern media and health messages (Erulkar et al. 2004b).

\section{Unsafe conditions of sexual activity}

The effective exclusion of young girls from HIV-prevention efforts has been fostered by ignorance and outright denial about the conditions of girls' sexual activity in adolescence. A great proportion of this activity takes place within marriage, and married girls often report their sexual initiation, and even their continuing marital sexual relationships, as forced (Erulkar et al. 2004b). Among unmarried girls, sexual initiation is also often coerced. Half of the poorest girls aged 14-24 in the Durban metro areas of KwaZulu-Natal report that their first sexual encounter was coerced (Hallman 2005). These girls are not included within conventional high-risk groups such as sex workers and drug users.

\section{Coming of age assetless and alone}

Early adolescence is a critical time when, for many girls, social and economic vulnerabilities are attended by serious threats to their health. In most countries, the transition from primary to secondary school takes place during early adolescence. Many families expect girls to leave school to begin working to help support the family economically. Those who remain in school during this period may confront threats to their safety and respectability that encourage them to leave school.

The absence of one or both parents-particularly in early adolescence-intensifies girls' vulnerability. In many subSaharan African countries, the majority of girls aged 10-14 living in urban areas are living with only one or no parent (Chong, Hallman, and Brady 2006). An even more extreme condition is found among children living with neither parent and out of school, as is the case for more than 8 percent of urban girls living in 18 sub-Saharan countries where DHS have been conducted since 2000; this proportion is as high as 18 percent in Burkina Faso and 21 percent in Mali. Without assets, skills, or any protection, these girls are prey to labor and sexual exploitation.

\section{Failing to reach the most vulnerable}

Rural and non-school-going populations, very young adolescents (particularly girls) living apart from their parents, and married girls are grossly underserved or totally absent from a wide array of youth-oriented programs. In a classic inversion of care, adolescents with the greatest advantages are being given the most resources, whereas those with the fewest social assets who are facing the greatest risks are being given the least.

A recent study in Addis Ababa, Ethiopia, where 30 percent of girls aged 10-14 are living with no parent, half of 1 percent of all programs were reaching such girls (Mekbib, Erulkar, and Belete 2005). The Ethiopian situation is not unusual. Similar patterns were observed in Burkina Faso, Guinea Bissau, and Mauritania. A study in Burkina Faso found that only 19 percent of the population served by urban youth centers were girls (younger girls-those aged 10-14-accounted for only 3 percent), whereas 36 percent of the "youth" served were men older than 20 (Lardoux 2006).

Married girls, who rarely participate in clubs, organizations, and programs, also have limited access to media messages, a situation with potentially grave consequences because the vast majority of girls' sexual activity during adolescence-94 percent in Ethiopia-takes place in the context of marriage (Bruce and Clark 2003). 
Even when programs reach married girls, current HIVprevention strategies-abstinence, reducing sexual frequency and the number of sexual partners, using condoms, knowing one's partner's HIV status, and avoiding sexual relations with infected partners-are virtually unachievable for them.

\section{Solutions: Moving ahead with the assets we have}

There are resources to address the situation: good laws can be implemented; entitlements can be extended; programs and, in many places, a substantial network of health, social, and economic services and citizenship initiatives can be reoriented to reach these girls and build their protective assets.

\section{Locating high concentrations of vulnerable girls}

We must do a much better job of finding and identifying girls and young women who are concentrated in communities with severe HIV epidemics by:

- analyzing data, such as those gathered by the Demographic and Health Surveys to locate girls in rural communities and urban neighborhoods, supplementing these with qualitative assessments;

- supporting child and community health initiatives that use house-to-house contact to identify girls and boys at risk; and

- locating services where vulnerable girls (and boys) connect or congregate, such as bus stops.

\section{Secure schooling through adolescence}

Getting girls to school on time and keeping them there through adolescence is critical. Missing school, even school of poor quality, means missing substantial didactic, social, and health (including reproductive health) benefits. A new generation of universal schooling programs holds some promise, although many school systems are barely functioning.

\section{Delayed, planned marriages to safe partners}

If laws prohibiting child marriage were enforced, girls would have a greater chance to delay sexual activity until they could legally choose the timing and conditions of marriage. Recognizing that marriage is not a sexual safety zone is crucial (Erulkar et al. 2004a and 2004b).

Pilot programs promoting a safe, healthy transition to marriage should be expanded. When presented with the opportunity, married girls have participated eagerly in clubs that offer catch-up schooling, functional literacy, life skills, livelihoods training, effective support for safe pregnancy and birth, and access to HIV-testing services and treatment (Erulkar et al. 2004b).

\section{Girls-only spaces}

Creating dedicated spaces for girls is a key strategy for the transformation of their self-awareness and expansion of their knowledge base and for providing a platform from which to offer them with vital health services, directly or by referral.

Safe spaces can be institutionalized at relatively low cost if they are established at public venues such as youth centers, community centers, and schools, or voluntary institutions, including faith-based organizations, churches, mosques, and local nongovernmental organizations. These exist in almost every community, and the investments have already been made, so that providing age- and genderspecific sessions can be made available to girls.

\section{Creating a crucial mentoring resource}

Girls' prospects for change are limited where no role models or mentoring structures of older females exist to support them. Young women who are high-school graduates and who are not employed constitute a valuable and underused resource. Experience shows that even in disadvantaged communities, female mentors, typically aged $17-30$, can be recruited for a small stipend. These young women speak the local languages, are rooted in and know the codes of the community, and can provide valuable mentoring to girls in need (Binti Pamoja Center 2006; Erulkar et al. 2006).

\section{Rethinking livelihood programs to meet girls' needs}

Girls across communities and income levels are enormously interested in developing livelihood skills and express interest in group affiliation, savings schemes, and financial literacy targeted to their age and context. Program venues created for girls and young women could be the basis for savings clubs where they could gain financial literacy, access to savings, and dignified work. Livelihoods programs must be adapted to meet their needs; microfinance experiments that pay insufficient attention to girls' social needs and that require loan-taking without an initial focus on financial literacy and savings increase girls' vulnerability (Population Council 2005; Erulkar et al. 2006). 


\section{Conclusion: Reframing adolescent girls' opportunities}

The social support and opportunity structures of adolescent girls can be systematically altered, and with these, the shape of the pandemic. Girls are important partners in this endeavor, but families and communities must be included. Otherwise, the youngest, poorest females will continue to bear a rising and disproportionate share of this human tragedy.

\section{References and related publications}

Binti Pamoja Center. 2006. "Financial literacy education: A curriculum for adolescent girls in Kibera Trainer's Guide." Washington, DC: The Global Financial Education Program.

Bruce, Judith and Shelley Clark. 2003. "Including married adolescents in adolescent reproductive health and HIVIAIDS policy," Background paper presented at WHO/UNFPA/Population Council Technical Consultation on Married Adolescents, Geneva, 9-12 December.

Bruce, Judith and Amy Joyce (eds). Forthcoming. "The girls left behind: The failed reach of current schooling, child health, youth-serving, and livelihood programs for girls living in the path of HIV." New York: Population Council.

Chong, Erica, Kelly Hallman, and Martha Brady. 2006. Investing When It Counts: Generating the Evidence Base for Policies and Programs for Very Young Adolescents-Guide and Tool Kit. New York: UNFPA and Population Council.

Clark, Shelley. 2004. "Early marriage and HIV risks in subSaharan Africa." Studies in Family Planning 35(3): 149-160.

Clark, Shelley, Judith Bruce, and Annie Dude. 2006. "Protecting girls from HIVIAIDS: The case against child and adolescent marriage." International Family Planning Perspectives 32(2): 79-88.

Erulkar, Annabel S., and James K. Matheka. 2007. Adolescents in the Kibera Slums of Nairobi, Kenya. Nairobi: Population Council.

Erulkar, Annabel, Tekle-Ab Mekbib, Negussie Simie, and Tsehai Gulema. 2004a. The Experience of Adolescence in Rural Amhara Region, Ethiopia. Accra, Ghana: Population Council.

—_ . 2004b. Adolescent Life in Low Income and Slum Areas of Addis Ababa, Ethiopia. Accra, Ghana: Population Council.

Erulkar, Annabel S., Judith Bruce, et al. 2006. Tap and Reposition Youth (TRY): Providing Social Support Savings, and Micro- credit Opportunities for Young Women in Areas with High HIV Prevalence. SEEDS No. 23. New York: Population Council.

Hallman, Kelly. 2004. "Socioeconomic Disadvantage and Unsafe Sexual Behaviors Among Young Women and Men in South Africa." Policy Research Division Working Paper No. 190. New York: Population Council.

2005. "Gendered socioeconomic conditions and HIV risk behaviours among young people in South Africa." African Journal of AIDS Research 41(1): 37-50.

Hallman, Kelly and Judith Diers. 2004. "Social isolation and economic vulnerability: Adolescent HIV and pregnancy risk factors in South Africa." Paper presented at the Annual Meeting of the Population Association of America, Boston, 1-3 April.

Hallman, Kelly, Kasthuri Govender, Emmanuel Mbatha, Rob Pattman, Deevia Bhana, and Jill Walsh. 2007. "Social capital, socioeconomic aspirations, and HIV risk behaviors among poor South African youth." Paper presented at the Third South African AIDS Conference, Durban, 6 June.

Lardoux, Solène. 2006. "Exercice de couverture des activités de paires educatuers au Burkina Faso: Rapport final." New York: UNFPA and Population Council.

Lloyd, Cynthia (ed.). 2005. "Schooling and adolescent reproductive behavior in developing countries." In Growing Up Global:The Changing Transitions to Adulthood in Developing Countries. Washington, DC: The National Academies Press.

Mekbib, Tekle-Ab, Annabel Erulkar, and F. Belete. 2005. "Who are the targets of youth programs?: Results of a capacity building exercise in Ethiopia." Ethiopian Journal of Health Development 19(1): 60-62.

Population Council. 2005. "Building assets for safe, productive lives: A report on a workshop on adolescent girls' livelihoods." Compiled by Erica Chong. New York: Population Council.

___. 2006. "How to conduct a coverage exercise: A rapid assessment tool for programs and services." New York: Population Council.

\section{Donors}

Dorothy and Lewis Cullman Foundation, UK Department for International Development (DFID), The Dickler Family Foundation, EMpower (The Emerging Markets Foundation), The Ford Foundation, Bill \& Melinda Gates Foundation, Nike Foundation, United Nations Foundation, United Nations Population Fund (UNPFA)

For more information or for copies of other briefs, contact publications@popcouncil.org For additional resources see www.popcouncil.org/pgy

Population Council

One Dag Hammarskjold Plaza

New York, New York 10017 USA

(c) 2007 by The Population Council, Inc. 